\title{
Methodiek schoolverlatersinformatiesysteem 1996
}

Citation for published version (APA):

Willems, E., \& van der Linden, I. (1998). Methodiek schoolverlatersinformatiesysteem 1996.

Researchcentrum voor Onderwijs en Arbeidsmarkt, Faculteit der Economische Wetenschappen. ROA Working Papers No. 1 https://doi.org/10.26481/umarow.1998001

Document status and date:

Published: 01/01/1998

DOI:

10.26481/umarow.1998001

Document Version:

Publisher's PDF, also known as Version of record

\section{Please check the document version of this publication:}

- A submitted manuscript is the version of the article upon submission and before peer-review. There can be important differences between the submitted version and the official published version of record.

People interested in the research are advised to contact the author for the final version of the publication, or visit the DOI to the publisher's website.

- The final author version and the galley proof are versions of the publication after peer review.

- The final published version features the final layout of the paper including the volume, issue and page numbers.

Link to publication

\footnotetext{
General rights rights.

- You may freely distribute the URL identifying the publication in the public portal. please follow below link for the End User Agreement:

www.umlib.nl/taverne-license

Take down policy

If you believe that this document breaches copyright please contact us at:

repository@maastrichtuniversity.nl

providing details and we will investigate your claim.
}

Copyright and moral rights for the publications made accessible in the public portal are retained by the authors and/or other copyright owners and it is a condition of accessing publications that users recognise and abide by the legal requirements associated with these

- Users may download and print one copy of any publication from the public portal for the purpose of private study or research.

- You may not further distribute the material or use it for any profit-making activity or commercial gain

If the publication is distributed under the terms of Article $25 \mathrm{fa}$ of the Dutch Copyright Act, indicated by the "Taverne" license above, 


\section{Methodiek Schoolverlatersinformatiesysteem 1996}

Ed Willems en Irma van der Linden

ROA-W-1998/1

Researchcentrum voor Onderwijs en Arbeidsmarkt

Faculteit der Economische Wetenschappen en Bedrijfskunde

Universiteit Maastricht

Maastricht, juni 1998 
ISBN 90-5321-234-5

SEC98.049/EW 
Inhoud

Bladzijde

Voorwoord $\quad$ i

1 Inleiding 1

2 Schoolverlatersonderzoeken 1

$3 \quad$ Dataverwerking en weging 3

$4 \quad$ Dekkingsgraad en respons $\quad 8$

5 Non-respons 11

6 Besluit 17

$\begin{array}{ll}\text { Literatuur } & 17\end{array}$

$\begin{array}{ll}\text { Appendix A: Kernvragenlijst } & 19\end{array}$ 


\section{Voorwoord}

Dit werkdocument gaat in op de methodiek die in het uitvoeringsjaar 1996 is gehanteerd binnen het schoolverlatersonderzoek, zoals dat door het ROA wordt uitgevoerd. Dit betreft de enquêtes Registratie en Bestemming van Schoolverlaters (RUBS), HBO-Monitor en WOMonitor. Vanaf 1996 is het ROA-schoolverlatersonderzoek in vergaande mate geïntegreerd. Hierdoor is een vergelijkbaar systeem ontstaan met gegevens over schoolverlaters uit vrijwel het gehele secundair en tertiair onderwijs, vooralsnog met uitzondering van een groot gedeelte van het wetenschappelijk onderwijs. Toch kan inmiddels worden gesproken van een Schoolverlatersinformatiesysteem. In het kader van het onderzoek binnen dit informatiesysteem zijn in 1996 onder andere het rapport Schoolverlaters tussen onderwijs en arbeidsmarkt 1996 en de bijbehorende bijlage Kerngegevens gepubliceerd (ROA, 1997a en 1997b). Daarnaast is een specifieke rapportage verschenen over de arbeidsmarktpositie van de afgestudeerden van het HBO (Van de Loo, Van der Velden en Zuurbier, 1997 en Van de Loo, Willems en Pagrach, 1997). Tevens zijn de belangrijkste resultaten van de WO-Monitor Economie in een landelijke rapportage samengebracht (Ramaekers, 1997).

Het Schoolverlatersinformatiesysteem wordt financieel mogelijk gemaakt door de Ministeries van Onderwijs, Cultuur en Wetenschappen, Sociale Zaken en Werkgelegenheid en Landbouw, Natuurbeheer en Visserij, het Landelijk Dienstverlenend Centrum voor Studie- en Beroepskeuzevoorlichting (LDC), de HBO-Raad en de deelnemende faculteiten en universiteiten aan de WO-Monitor. Bij de uitvoering van het onderzoek werkt het ROA samen met DESAN Marktonderzoek b.v. te Amsterdam. Binnen het ROA is de projectleiding van het Schoolverlatersinformatiesysteem in handen van dr. R.K.W. van der Velden en drs. E.J.T.A. Willems. Dit werkdocument is samengesteld door drs. E.J.T.A. Willems en drs. A.S.R. van der Linden. Verder hebben aan het Schoolverlatersinformatiesysteem 1996 meegewerkt A.M. Kleijnen, drs. P.J.E. van de Loo, J.M.J.A. Pisters, drs. G.W.M. Ramaekers, B.J. Weerkamp en drs. H.M. Zuurbier (allen werkzaam bij ROA), alsmede drs. K.R. Becker, drs. H. van Dongen, drs. ing. K.J. Pagrach en ing. J.J. Rutjes (allen werkzaam bij DESAN Marktonderzoek). 


\section{$1 \quad$ Inleiding}

Door het ROA worden jaarlijks enkele grootschalige schoolverlatersonderzoeken uitgevoerd. Enerzijds betreft dit een onderzoek onder de schoolverlaters van het Algemeen Voortgezet Onderwijs (AVO), het Voorbereidend Beroepsonderwijs (VBO) en het Middelbaar Beroepsonderwijs (MBO) aan de hand van de enquête Registratie van Uitstroom en Bestemming van Schoolverlaters (RUBS). Anderzijds is dit een onderzoek onder de afgestudeerden van het Hoger Beroepsonderwijs (HBO) in de HBO-Monitor en onder de afgestudeerden van het kunstvakonderwijs in de Kunsten-Monitor. Daarnaast wordt onderzoek verricht onder de afgestudeerden van de Universiteit Maastricht en de Technische Universiteit Delft, alsmede onder de afgestudeerden van de economische faculteiten van de Erasmus Universiteit Rotterdam, de Katholieke Universiteit Brabant, de Universiteit van Amsterdam en de Vrije Universiteit in de WO-Monitor. Deze schoolverlatersonderzoeken vormen onder andere de basis voor een aantal landelijke publicaties, zoals de recent verschenen rapporten Schoolverlaters tussen onderwijs en arbeidsmarkt 1996 en De arbeidsmarktpositie van afgestudeerden van het hoger beroepsonderwijs; HBO-Monitor 1996 en WO-Monitor economie 1996; Basismeting cohort '95.

Dit werkdocument vormt een methodologische aanvulling op deze reeds verschenen rapporten. Er zal met name ingegaan worden op de gehanteerde methodiek en op het uitgevoerde non-responsonderzoek. De opzet van de rest van dit werkdocument is als volgt. Allereerst wordt in paragraaf 2 een uiteenzetting gegeven over het doel en de opzet van de schoolverlatersonderzoeken. Vervolgens wordt in paragraaf 3 ingegaan op de dataverwerking en de weging van de gegevens. In paragraaf 4 wordt daarna een overzicht gegeven van de dekkingsgraad en de respons. Paragraaf 5 bevat het verslag van het non-responsonderzoek. In paragraaf 6 wordt dit werkdocument ten slotte kort samengevat.

\section{Schoolverlatersonderzoeken}

Doel

De schoolverlatersenquêtes van het ROA zijn gericht op het monitoren en analyseren van de bestemming van (gediplomeerde) schoolverlaters in het vervolgonderwijs en op de arbeidsmarkt. Aandachtspunten daarbij zijn het individuele keuzegedrag ten aanzien van (vervolg-)onderwijs, de arbeidsmarktpositie van opleidingen, het zoekgedrag en het beroepsmatig functioneren van schoolverlaters, hun initiële loopbanen en de evaluatie van het curriculum.

Binnen de schoolverlatersonderzoeken van het ROA kunnen twee componenten worden onderscheiden: een toepassingscomponent en een onderzoekscomponent. De toepassingscomponent richt zich op de zorg van individuele onderwijsinstellingen voor de 
onderwijskwaliteit en de afstemming van het onderwijs op de behoeften van de arbeidsmarkt. Daarvoor worden zogenaamde instellingsrapportages opgesteld waarin de onderwijsinstellingen informatie krijgen over hun 'eigen' afgestudeerden, waar relevant afgezet tegen het landelijke beeld. Hiermee kunnen management, studierichtingsleiders en decanaat een indruk verkrijgen van het externe rendement van de eigen afgestudeerden.

De onderzoekscomponent van het schoolverlatersonderzoek, aangeduid als het Schoolverlatersinformatiesysteem, heeft als doel het analyseren van het doorstroompatroon van schoolverlaters naar vervolgonderwijs en het transitieproces van school naar werk. De resultaten hiervan worden onder meer gepubliceerd via algemeen toegankelijke landelijke rapportages. Hierin ligt het accent op (de ontwikkelingen in) het intredeproces van schoolverlaters, de kansen op het vinden van werk, de kwaliteit van het werk en het keuzegedrag van schoolverlaters ten aanzien van mogelijke vervolgopleidingen en de kwaliteit van de aansluiting die daarbij wordt ondervonden.

\section{Opzet}

Zoals reeds eerder is aangegeven, vormt een drietal schoolverlatersonderzoeken, te weten RUBS, de HBO-Monitor en de WO-Monitor, de basis van het Schoolverlatersinformatiesysteem. Voor al deze schoolverlatersonderzoeken geldt dat onderwijsinstellingen zelf aangeven of zij met (een deel van) hun schoolverlaters of afgestudeerden willen deelnemen'. Er is derhalve geen sprake van een aselecte steekproef. Mochten er echter 'witte vlekken' in de deelname ontstaan - zowel naar opleidingsrichting of regio - dan wordt een aanvullende steekproef getrokken. In 1996 bleek dat echter nauwelijks noodzakelijk. Voor het WO wordt overigens geen aanvullende steekproef getrokken en is het onderzoek vooralsnog beperkt tot enkele deelnemende universiteiten en faculteiten².

Sinds het uitvoeringsjaar 1996 wordt het schoolverlatersonderzoek van het ROA uitgevoerd volgens een geïntegreerd model, waarbij één meetmoment en één kernvragenlijst wordt onderscheiden. In de praktijk betekent dit dat in oktober ${ }^{3} 1996$ ruim 75.000 schoolverlaters en afgestudeerden van het school-/studiejaar 1994/1995 zijn benaderd met een schriftelijke vragenlijst. Wanneer schoolverlaters na ruim een maand de vragenlijst nog niet teruggestuurd hebben, wordt een rappèl verstuurd. In sommige gevallen is tevens telefonisch gerappelleerd.

1. De RUBS-enquête wordt bij de scholen aangeboden onder verantwoordelijkheid van het LDC. De HBO-Monitor wordt bij de hogescholen aangeboden onder auspiciën van de HBO-Raad. Het ROA biedt zelf de WO-Monitor aan bij de universiteiten of faculteiten. Binnen het agrarisch onderwijs wordt zowel de RUBS-enquête als de HBO-Monitor aangeboden door bureau Arbeidsmarktonderzoek van STOAS te Wageningen.

2. Vanaf 1998 zal er in VSNU-verband een WO-Monitor onder de afgestudeerden van alle Nederlandse universiteiten worden gehouden.

3. In voorgaande jaren werden de schoolverlaters binnen RUBS in mei benaderd, dat wil zeggen zo'n tien maanden na het verlaten van de opleiding. Bij de HBO- en de WO-Monitor werden de vragenlijsten ook in het verleden in het najaar verstuurd. 
Ofschoon de vragenlijsten in de kern gelijk zijn, is in het uitvoeringsjaar 1996 gebruik gemaakt van maar liefst 13 verschillende vragenlijsten, om zodoende recht te doen aan de verschillen die er tussen de diverse onderwijsniveaus of -sectoren bestaan. Binnen RUBS zijn aparte lijsten gebruikt voor de schoolverlaters van de MAVO, van HAVO/VWO, van VBO en van MBO. Voor het agrarisch onderwijs op zowel VBO- als MBO-niveau zijn specifieke vragenlijsten gebruikt. Voorts zijn de schoolverlaters van het AVO en VBO in de gemeente Amsterdam met specifieke vragenlijsten benaderd, omdat hier een afwijkende onderzoekopzet is gehanteerd ${ }^{4}$. Ook binnen de HBO-Monitor is een aparte vragenlijst opgesteld voor de afgestudeerden van het landbouwonderwijs. Daarnaast zijn onder de naam Kunsten-Monitor twee specifieke vragenlijsten opgesteld voor afgestudeerden van het kunstvakonderwijs, respectievelijk vragenlijsten voor HBO Beeldende Kunst en Vormgeving en HBO Muziek en Theater. Om een hogere respons te bereiken, is onder afgestudeerden van het kunstvakonderwijs die de schriftelijke vragenlijst niet hebben teruggestuurd een beperkt gedeelte van de vragenlijsten telefonisch afgenomen.

De vragenlijsten van het uitvoeringsjaar 1996 bestaan uit een viertal hoofd-onderwerpen: algemeen (geslacht, leeftijd e.d.), onderwijsloopbaan, arbeidsmarktintrede en een thematisch gedeelte. Binnen de vragenlijsten voor het AVO en het VBO ligt de nadruk op de doorstroom naar het vervolgonderwijs en de redenen van eventuele uitval. Tevens wordt in deze vragenlijsten uitgebreid stilgestaan bij de rol van studie- en beroepskeuzebegeleiding. Er wordt slechts in beperkte mate ingegaan op de arbeidsmarktintrede van schoolverlaters. In de overige vragenlijsten ligt de nadruk juist op het transitieproces van school naar werk en wordt minder vergaand gevraagd naar de doorstroom naar vervolgonderwijs. In het thematisch gedeelte is in 1996 aandacht besteed aan 'de eerste baan'. Overigens is dit thema-deel alleen opgenomen in de vragenlijsten voor schoolverlaters van het MBO en hoger. Appendix A geeft een overzicht van het kern-deel van de vragenlijst.

\section{Dataverwerking en weging}

Nadat de vragenlijsten verzameld zijn, start het dataverwerkingsproces. Hierbij wordt de informatie op de vragenlijsten omgezet tot een bestand dat geschikt is voor het uitvoeren van analyses. Dit proces van dataverwerking bestaat uit een aantal stappen: de codering van enkele vragen met 'open' antwoordcategorieën (waaronder vervolgopleiding, beroep, bedrijfssector), de data-entry, de opschoning van het bestand voor mogelijke inconsistenties ('datacleaning') en de uitbreiding van het bestand met nieuwe variabelen. Vervolgens wordt het bestand gewogen, zodat op basis van de gegevens landelijk representatieve uitspraken

4. De deelname van de Amsterdamse schoolverlaters is mogelijk gemaakt via het bureau O\&S van de gemeente Amsterdam in samenwerking met OCTANT. De adresvergaring heeft plaatsgevonden op basis van de gemeentelijke gegevens. Deze gegevens bleken overigens sterk vervuild, waardoor een groot aantal personen ten onrechte is aangeschreven: zij waren geen schoolverlater in de desbetreffende periode. Op verzoek van O\&S zijn tevens enkele additionele vragen aan de schoolverlaters gesteld. 
kunnen worden gedaan.

\section{Dataverwerking}

De vragenlijsten bevatten voor het merendeel gesloten antwoordcategorieën, waarbij de respondenten kunnen kiezen uit een aantal voorgedrukte mogelijkheden. In een beperkt aantal gevallen dienen de schoolverlaters zelf een numerieke waarde in te vullen, bijvoorbeeld bij leeftijd, inkomen en aantal gewerkte uren. Bij enkele vragen wordt echter gebruik gemaakt van een volledig 'open' vraagstelling, waarbij de schoolverlaters zelf het antwoord op de vraag moeten omschrijven. Dit is met name het geval bij vragen waar het gaat om:

- soort (vervolg- en voor-)opleiding;

- beroep;

- bedrijfssector;

- (woon- of werk-)gemeente.

Bij deze vragen worden de alfanumerieke antwoorden van de respondenten gecodeerd volgens vooraf opgestelde classificaties. Voor de opleidingsvragen wordt daarbij gebruik gemaakt van een speciaal voor dit doel door het ROA opgestelde opleidingsclassificatie, waarin alle in Nederland voorkomende (reguliere) opleidingen zijn opgenomen ${ }^{5}$. Beroep en bedrijfssector worden gecodeerd volgens de Standaard Beroepen Classificatie 1992 (SBC92) en de Standaard Bedrijfsindeling 1993 (SBI93) van het CBS. Overigens zijn beide classificaties, waar relevant, door het toevoegen van een extra digit verder verbijzonderd. Gemeenten worden gecodeerd volgens de gemeentecodes die door het CBS in het meest recente Plaatsnamenregister worden gehanteerd.

De aldus verkregen 'ruwe' gegevens worden wordt vervolgens onderworpen aan een uitgebreide kwaliteitscontrole. Doel van deze controles is eventuele onvolkomenheden, fouten en inconsistenties te achterhalen en zo mogelijk te corrigeren ${ }^{6}$. Het proces van kwaliteitscontrole van de gegevens is in een vijftal fasen onderverdeeld:

1. Eerste controle: dit is een algemene controle om te achterhalen of er bij de data-entry problemen zijn opgetreden en of de gegevens ten aanzien van de gevolgde opleiding juist zijn.

2. Controle op stringvariabelen: hierin wordt bekeken of er bij de vragen met een antwoordcategorie "anders, namelijk ..." bepaalde grote groepen kunnen worden onderscheiden.

5. De Standaard Onderwijs Indeling (SOI) van het CBS is voor het schoolverlatersonderzoek niet geschikt. Deze classificatie is sterk verouderd en maakt enkele belangrijke onderscheiden binnen het onderwijssysteem niet. Zo wordt bijvoorbeeld binnen de SOI het leerlingwezen, kort MBO en MBO niet van elkaar onderscheiden. Ook moeten nieuwe opleidingen vaak onder de noemer 'niet eerder geclassificeerd' worden ondergebracht. Overigens voorziet de classificatie wel in een koppeling met de SOI.

6. Overigens is een groot aantal controles reeds in de data-entry opgenomen. Dit betreft met name controles op grenswaarden en controles op de in de vragenlijsten gehanteerde routings. 
3. Controles per blok ${ }^{7}$ : in deze fase wordt gecontroleerd of de antwoorden op de vragen die bij elkaar horen, overeen kunnen komen. Een voorbeeld kan dit verduidelijken. Stel dat het antwoord op de vraag "volg je deze vervolgopleiding nog steeds" ontbreekt, terwijl de vraag waarom de schoolverlater gestopt is wel ingevuld is. In dat geval wordt het ontbrekende antwoord op de eerste vraag vervangen door "nee, voortijdig verlaten".

4. Controles over de blokken heen: hierin wordt nagegaan of de antwoorden op de vragen van verschillende blokken met elkaar overeenstemmen. Bijvoorbeeld: wanneer de eerste maanden van de 'kalender' met belangrijkste bezigheden per maand niet ingevuld zijn en de eerste wel ingevulde maand de maand van afstuderen of de eerste maand ná het afstuderen is, dan worden de eerste maanden van de kalender gevuld met "scholier/student".

5. Afronding cleaning: tot slot van de cleaning worden de cases die niet bruikbaar zijn uit het bestand verwijderd. Dit zijn onder andere de cases die onverwerkbaar zijn doordat vitale informatie ontbreekt en de cases die niet tot de doelgroep behoren (met name schoolverlaters die in een ander jaar de opleiding hebben verlaten).

In principe is het bestand na de cleaning klaar voor gebruik. Om de bruikbaarheid ervan echter te vergemakkelijken wordt er tevens een aantal nieuwe variabelen aan het bestand toegevoegd. Veelal zijn dit variabelen die veelvuldig afgeleid zouden moeten worden voor de analyses. Zo is bijvoorbeeld voor de variabele 'beroepsbevolking' de antwoorden op meer dan vijf vragen nodig.

\section{Weging}

De deelname van de scholen aan de schoolverlatersonderzoeken geschiedt, zoals vermeld in paragraaf 2, op vrijwillige basis. Hierdoor ontstaat er in de regel een ongelijke spreiding naar opleiding en regio. Ook naar andere kenmerken van de populatie kan er een scheefheid in de verdeling ontstaan. Zo is de respons bij vrouwen in het algemeen hoger dan bij mannen, waardoor vrouwen oververtegenwoordigd zijn in het onderzoeksbestand. Dergelijke ongelijkheden leiden ertoe dat het onderzoeksbestand geen landelijke representatie is van de doelgroep. Om toch betrouwbare landelijke gegevens te kunnen presenteren, wordt een weging uitgevoerd op het bestand zoals dat na de dataverwerking is verkregen. Daarbij wordt een zodanige weging uitgevoerd dat de aantallen corresponderen met de aantallen in de populatie (ophoging).

Voor de weging wordt gebruik gemaakt van de populatiegegevens die beschikbaar zijn op basis van de Integrale Leerlingtelling (ILT), voor wat betreft het voortgezet onderwijs en het (kort) MBO, en het Centraal Register Instellingen Hoger Onderwijs (CRIHO), voor wat betreft het HBO. Beide databestanden worden beheerd door het Ministerie van Onderwijs, Cultuur en Wetenschappen. Ten aanzien van de schoolverlaters van de landbouwopleidingen wordt

7. Blokken in de vragenlijsten zijn bijvoorbeeld "Gevolgde opleiding", "Vervolgopleiding", "Belangrijkste bezigheden" en "Kenmerken huidige functie". 
gebruik gemaakt van door het Ministerie van Landbouw, Natuurbeheer en Visserij beschikbaar gestelde gegevens. In de ILT 1994/1995 zijn per instelling en per opleiding gegevens beschikbaar over het aantal leerlingen per leerjaar en geslacht ${ }^{8}$. Het $\mathrm{CRIHO}$ bevat per instelling

en opleiding gegevens over het aantal diploma's, waarbij eveneens een onderverdeling naar geslacht is gemaakt. Bovendien wordt bij de opleidingen een onderscheid gemaakt tussen de voltijd- en de deeltijdopleidingen.

In principe wordt op het niveau van opleiding $x$ voltijd/deeltijd (alleen HBO) $x$ regio $x$ geslacht een wegingsfactor bepaald als het quotiënt van het aantal in de populatie en het aantal in het onderzoeksbestand. Indien echter de resulterende weegfactor groter is dan 3 maal de gemiddelde weegfactor en bovendien het aantal cases dat wordt gewogen kleiner is dan 50 , dan wordt eerst de dimensie geslacht en indien vervolgens noodzakelijk ook de dimensie regio buiten beschouwing gelaten. In dat geval wordt derhalve gewogen op het niveau van opleiding $x$ voltijd/deeltijd (alleen HBO) $x$ regio, respectievelijk opleiding $x$ voltijd/deeltijd (alleen HBO). Voor opleidingen waar het aantal werkenden in de respons minder dan 15 bedraagt heeft voorafgaand aan de weging een clustering plaatsgevonden. Op dit hogere clusterniveau wordt vervolgens de weging uitgevoerd. Overigens worden in de regel in de schoolverlatersonderzoeken geen landelijke gegevens gepresenteerd wanneer deze betrekking hebben op minder dan 15 respondenten. Tabel 3.1 geeft een overzicht van de aantallen schoolverlaters per opleidingssector vóór en ná de weging. Bij het HBO is daarbij tevens een onderscheid gemaakt naar voltijd en deeltijd.

Tabel 3.1

Aantallen schoolverlaters per opleidingssector in het ongewogen en gewogen bestand, 1996

\begin{tabular}{lrr} 
Opleidingssector & $\begin{array}{c}\text { Ongewogen } \\
\text { aantal }\end{array}$ & $\begin{array}{c}\text { Gewogen } \\
\text { aantal }\end{array}$ \\
\hline AVO & 3.135 & 118.500 \\
MAVO & 898 & 52.000 \\
HAVO & 1.188 & 34.900 \\
VWO & 1.049 & 31.400
\end{tabular}

8. Helaas zijn gegevens over het aantal gediplomeerden met ingang van dit jaar vanwege privacyredenen niet meer beschikbaar gesteld. Om toch rekening te houden met het rendement van het laatste leerjaar is hiervoor gebruikt gemaakt van gegevens van het voorgaande jaar. Naar verwachting zullen de rendementscijfers in één jaar niet aan hevige veranderingen onderhevig zijn. 
Tabel 3.1 (vervolg)

Aantallen schoolverlaters per opleidingssector in het ongewogen en gewogen bestand, 1996

\begin{tabular}{|c|c|c|}
\hline Opleidingssector & $\begin{array}{l}\text { Ongewogen } \\
\text { aantal }\end{array}$ & $\begin{array}{c}\text { Gewogen } \\
\text { aantal }\end{array}$ \\
\hline VBO & 1.090 & 50.300 \\
\hline landbouw & 410 & 4.200 \\
\hline techniek & 276 & 25.000 \\
\hline economie & 196 & 10.100 \\
\hline gezondheidszorg & 208 & 11.100 \\
\hline MBO-kort & 1.195 & 25.800 \\
\hline oriënteren en schakelen & 156 & 8.400 \\
\hline landbouw & 159 & 500 \\
\hline techniek & 230 & 5.200 \\
\hline economie & 457 & 9.300 \\
\hline gezondheidszorg & 193 & 2.400 \\
\hline MBO & 7.393 & 67.300 \\
\hline landbouw & 889 & 4.000 \\
\hline techniek & 1.761 & 22.800 \\
\hline economie & 2.241 & 25.100 \\
\hline gezondheidszorg & 1.711 & 9.600 \\
\hline gedrag en maatschappij & 791 & 5.800 \\
\hline HBO voltijd & 13.346 & 41.300 \\
\hline landbouw & 976 & 4.200 \\
\hline onderwijs & 1.245 & 5.900 \\
\hline techniek & 3.021 & 10.200 \\
\hline economie & 4.325 & 10.400 \\
\hline gezondheidszorg & 1.009 & 3.200 \\
\hline gedrag en maatschappij & 1.409 & 4.000 \\
\hline kunst en cultuur & 1.361 & 3.400 \\
\hline HBO deeltijd & 2.134 & 9.500 \\
\hline landbouw & 25 & 100 \\
\hline onderwijs & 487 & 3.300 \\
\hline techniek & 91 & 400 \\
\hline economie & 228 & 1.100 \\
\hline gezondheidszorg & 294 & 1.600 \\
\hline gedrag en maatschappij & 779 & 2.300 \\
\hline kunst en cultuur & 230 & 600 \\
\hline$W O^{\mathrm{a}}$ & 2.962 & \\
\hline
\end{tabular}

a. Bij het WO heeft geen weging plaatsgevonden (wegingsfactor 1), zodat de gewogen aantallen gelijk zijn aan de ongewogen aantallen. 


\section{Dekkingsgraad en respons}

De schoolverlaters die uiteindelijk in het onderzoeksbestand zijn opgenomen, vormen slechts een gedeelte van de gehele onderzoekspopulatie. Enerzijds worden niet álle personen uit de doelgroep benaderd en anderzijds reageert niet iedereen die wél is benaderd. De dekkingsgraad geeft een beeld van de omvang van het gedeelte van de populatie dat benaderd is. Het responspercentage geeft vervolgens aan welk deel van degenen die benaderd zijn daadwerkelijk gereageerd heeft.

Tabel 4.3 geeft vervolgens een overzicht van de in 1996 uitgezette en (niet) terugontvangen vragenlijsten. De belangrijkste traceerbare reden van non-respons is het ontbreken van een actueel adres. In bijna $4 \%$ van de aangeschrevenen is dit het geval. Tabel 4.4 geeft aansluitend de responspercentages per opleidingssector. Evenals in tabel 3.1 is er bij het HBO tevens een onderscheid gemaakt naar voltijd en deeltijd.

De respons is duidelijk het grootste bij de schoolverlaters van het AVO. Bij het VWO wordt zelfs een respons van $78 \%$ bereikt. Bij het kort $\mathrm{MBO}$ is helaas sprake van een vrij lage respons: $39 \%$. Het MBO en het $\mathrm{HBO}$ kent responspercentages van rond de $55 \%$. Dit is gelijk aan hetgeen ook de afgelopen jaren is bereikt. Het WO kent een hogere respons $61 \%$.

\section{Dekkingsgraad}

Tabel 4.1 laat voor 1996 zien hoe groot de dekkingsgraad per schooltype is ${ }^{9}$. De tabel laat zien dat er tussen de verschillende schooltypen een groot verschil in dekkingsgraad bestaat. Vooral bij het $\mathrm{HBO}$ is sprake van een zeer hoge deelname, waardoor een dekking van maar liefst $60 \%$ wordt bereikt. Bij het AVO en VBO ligt deze deelname aanzienlijk lager. Hier is zo'n 10$15 \%$ van de schoolverlaters benaderd. Het kort MBO en het MBO neemt een middenpositie in met deelnamepercentage van respectievelijk $20 \%$ en $26 \%$.

Tabel 4.1

Dekkingsgraad per schooltype, 1996

\begin{tabular}{lcc} 
Schooltype & $\begin{array}{c}\text { Benaderd } \\
\text { aantal }\end{array}$ & $\begin{array}{c}\text { Dekking } \\
\%\end{array}$ \\
\hline & & \\
AVO & 12.028 & 10 \\
VBO & 7.072 & 14 \\
MBO-kort & 5.151 & 20 \\
MBO & 17.588 & 60 \\
HBO & 30.529 & 60
\end{tabular}

Tabel 4.2

9. Het WO is hier buiten beschouwing gelaten. 
Berekening van de respons: omschrijving teller en noemer van het responspercentage ${ }^{a}$

Omschrijving

$\begin{array}{ccc}\text { Teller } & \text { Noemer } & \text { Onderzoeks- } \\ \text { respons } & \text { respons } & \text { bestand }\end{array}$

Schriftelijk gereageerd

Telefonisch gereageerd (kunstvakonderwijs)

Overleden

Onbestelbaar retour

Onbereikbaar i.v.m. verblijf buitenland/ernstige ziekte

Weigering: anonimiteit of andere reden

Mismatch onderzoeksbestand/administratiebestand

$\mathrm{Na}$ sluitingsdatum ontvangen

Onverwerkbaar

Ongediplomeerde afgestudeerden

65 Jaar of ouder

Afstudeerjaar individuele afgestudeerden verkeerd

Afstudeerjaar gehele opleiding/faculteit verkeerd

AVO/VBO Amsterdam ${ }^{b}$ aanwijsbaar probleem

$\begin{array}{lll}v & v & v \\ v & v & v \\ x & x & x \\ x & v & x \\ x & v & x \\ x & v & x \\ v & v & x \\ v & v & x \\ v & v & x \\ v & v & x^{c} \\ v & v & x \\ v & v & x \\ x & x & x^{c} \\ x & x & v\end{array}$

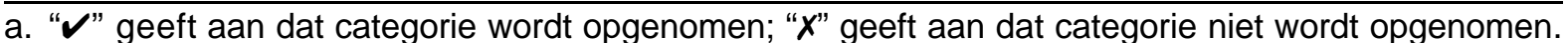
Overigens betekent het opnemen van een categorie bij de bepaling van de respons niet automatisch dat deze categorie ook in het onderzoekbestand wordt opgenomen (zie laatste kolom)

b. Door een afwijkende vorm van adresvergaring zijn de in Amsterdam uitgezette en ontvangen vragenlijsten buiten beschouwing gelaten bij het bepalen van de respons, omdat hier geen goed beeld van de feitelijke aangeschreven populatie voorhanden is.

c. Deze categorie is uitsluitend opgenomen in het bestand met het oog op de instellingsrapportages. Voor landelijke rapportages wordt deze groep buiten beschouwing gelaten.

Tabel 4.3

Resultaat dataverzameling in aantallen per schooltype

$\mathrm{AVO}^{\mathrm{a}} \quad \mathrm{VBO}^{\mathrm{a}} \mathrm{MBO}-k$ rt $\mathrm{MBO}$ HBO WO Totaal

Totaal uitgezet

$12.028 \quad 7.072$

$5.151 \quad 17.58830 .529 \quad 4.889$

77.256

Retour ontvangen, beschikbaar voor verwerking

$\begin{array}{lllllll}3.260 & 1.180 & 1.437 & 7.888 & 15.526 & 2.962 & 32.253\end{array}$

Retour ontvangen, niet geschikt voor verwerking, vanwege

- onbestelbaar retour

- weigering: anonimiteit of andere reden

- onverwerkbaar

- school-/studiejaar verkeerd

- AVO/VBO A'dam aanwijsbaar probleem

- overige redenen

$\begin{array}{rrrrrrr}203 & 205 & 239 & 670 & 1.278 & 200 & 2.795 \\ 11 & 30 & 43 & 88 & 50 & 4 & 226 \\ 3 & 5 & 10 & 7 & 31 & & 56 \\ 91 & 452 & 92 & 459 & 544 & 68 & 1.706 \\ 885 & 458 & & & & & 1.346 \\ 10 & 6 & 4 & 29 & 60 & 8 & 117\end{array}$

a. Bekend is dat voor de gemeente Amsterdam veel schoolverlaters ten onrechte zijn aangeschreven. Naar verwachting heeft slechts een klein deel van de aangeschrevenen dit expliciet gemeld, waardoor het aantal retour ontvangen ten opzichte van het aantal uitgezette vragenlijsten erg laag is.

Respons 
Het responspercentage wordt berekend als het quotiënt van het aantal terug ontvangen vragenlijsten en het aantal uitgezette vragenlijsten. Maar wat wordt precies meegenomen in de teller van het responspercentage en wat in de noemer? Het antwoord op deze vraag wordt gegeven in tabel 4.2. Tevens wordt in deze tabel aangegeven of de desbetreffende cases in het onderzoekbestand worden opgenomen.

Tabel 4.4

Responspercentage per opleidingssector, $1996^{\mathrm{a}}$

Opleidingssector

$\%$

$\begin{array}{ll}\text { AVO } & 69\end{array}$

MAVO $\quad 59$

HAVO $\quad 70$

VWO $\quad 78$

$\begin{array}{ll}V B O & 47\end{array}$

landbouw $\quad 41$

techniek 52

economie $\quad 59$

$\begin{array}{ll}\text { gezondheidszorg } & 49\end{array}$

MBO-kort 39

oriënteren en schakelen $\quad 37$

landbouw $\quad 40$

techniek 36

economie $\quad 40$

$\begin{array}{ll}\text { gezondheidszorg } & 46\end{array}$

MBO 54

landbouw $\quad 53$

techniek $\quad 50$

economie $\quad 55$

gezondheidszorg $\quad 59$

gedrag en maatschappij 53

HBO voltijd

landbouw $\quad 58$

onderwijs 49

techniek 53

economie $\quad 53$

gezondheidszorg $\quad 55$

gedrag en maatschappij 53

kunst en cultuur $\quad 54$ 
Tabel 4.4 (vervolg)

Responspercentage per opleidingssector, $1996^{a}$

Opleidingssector

$\%$

$\begin{array}{lr}\text { HBO deeltijd } & 52 \\ \text { landbouw } & 67 \\ \text { onderwijs } & 45 \\ \text { techniek } & 52 \\ \text { economie } & 44 \\ \text { gezondheidszorg } & 55 \\ \text { gedrag en maatschappij } & 56 \\ \text { kunst en cultuur } & 67 \\ \text { wO } & 61\end{array}$

a. Bij de percentages voor AVO en VBO zijn de in de gemeente Amsterdam uitgezette en ontvangen vragenlijsten buiten beschouwing gelaten, omdat hier - door een afwijkende vorm van adresvergaring - geen goed beeld van de feitelijke aangeschreven populatie voorhanden is. Overigens wordt opgemerkt dat de respons onder die groep wel beduidend lager ligt.

\section{Non-respons}

Zoals in paragraaf 4 is aangegeven, varieert de respons van het schoolverlatersonderzoek van $39 \%$ voor het kort MBO tot $69 \%$ voor het AVO. De resultaten zoals die beschreven staan in de landelijke en instellingsrapportages zijn vanzelfsprekend gebaseerd op deze responsgroep. Om te achterhalen of de onderzoeksresultaten die verkregen worden door gebruik te maken van de gegevens van deze responsgroep geen vertekening van de werkelijkheid vormen, is het belangrijk om te weten of er sprake is van een selectieve respons. Stel bijvoorbeeld dat de schoolverlaters die werkloos zijn in grote getale weigeren aan de enquête deel te nemen. Het werkloosheidspercentage dat berekend wordt met behulp van de gegevens van de responsgroep laat in dat geval een onderschatting van het werkelijke werkloosheidspercentage zien.

Eventuele selectiviteit van de respons kan worden nagegaan door op enkele belangrijke kenmerken de responsgroep met de non-responsgroep te vergelijken. Dit is in principe op twee manieren mogelijk: (1) door de kenmerken van de responsgroep te vergelijken met de kenmerken van de doelgroeppopulatie welke reeds op basis van andere bronnen bekend zijn of (2) door een aanvullend onderzoek te houden onder de non-responsgroep, waarbij over enkele kernvariabelen informatie wordt ingewonnen. Ten aanzien van het schoolverlatersonderzoek is vooraf nauwelijks enige informatie bekend, behoudens gevolgde opleiding, geslacht en regio. Aangezien deze gegevens echter reeds gebruikt worden om het onderzoekbestand te herwegen - waardoor op deze punten een landelijk representatief beeld ontstaat - is voor het nagaan van de representativiteit ten aanzien van enkele kernvariabelen derhalve een non-responsonderzoek noodzakelijk. 
De vraag is vervolgens over welke kenmerken van de non-responsgroep informatie verzameld dient te worden. Het antwoord wordt bepaald door het belang dat binnen het schoolverlatersonderzoek aan de verschillende kenmerken wordt gehecht en de mate waarin verwacht mag worden dat de respons op deze punten selectief is. De bestemming oftewel de maatschappelijke positie van schoolverlaters na het verlaten van de opleiding kan beschouwd worden als één van de belangrijkste kernpunten in de schoolverlatersenquêtes. Bovendien zou juist op dit punt selectiviteit in de respons kunnen ontstaan. Evenals in voorgaande jare ${ }^{10}$ is het non-responsonderzoek voor het uitvoeringsjaar 1996 daarom vooral toegespitst op de bestemming van schoolverlaters.

Een ander belangrijk aspect binnen het schoolverlatersonderzoek omvat het onderzoek onder degenen die betaald werk verrichten. Daarom wordt in het non-responsonderzoek ook getoetst op eventuele selectiviteit in de antwoorden op de vraag "Heb je op dit moment (ook) betaald werk? (inclusief een betaalde bijbaan en/of een leer-arbeidsplaats)". Behalve het bestaan van eventuele selectiviteit tussen de respondenten en de non-respondenten ten aanzien van de twee genoemde variabelen bestemming en betaald werk, wordt er vanuit gegaan dat er geen selectiviteit is opgetreden ten aanzien van de overige variabelen in de vragenlijst. Zo is er bijvoorbeeld geen grond om aan te nemen dat degenen die naar een technische vervolgopleiding zijn gegaan vaker of minder vaak reageren dan degenen die een economische vervolgopleiding zijn gaan volgen ${ }^{11}$ of dat degenen die van beroep timmerman zijn vaker of minder vaak responderen dan degenen die elektricien van beroep zijn.

\section{Non-responsonderzoek}

Het non-responsonderzoek voor 1996 heeft plaatsgevonden aan de hand van een korte telefonische enquête. Deze is gehouden onder een steekproef van degenen die in eerste instantie de schriftelijke vragenlijst niet hebben geretourneerd. De opleidingssector HBO kunst en cultuur vormt een uitzondering op de steekproeftrekking: hiervan zijn de non-respondenten, zoals eerder is aangegeven, integraal benaderd. Onder de afgestudeerden van het WO is geen non-responsonderzoek gehouden.

De steekproef van het non-responsonderzoek 1996 is gestratificeerd naar schooltype. Binnen een schooltype wordt aselect getrokken over de verschillende opleidingssectoren. Achteraf bleek echter de sector landbouw binnen het VBO sterk oververtegenwoordigd te zijn in het non-responsonderzoek. Dit heeft te maken met enerzijds de vrijwel integrale deelname van deze sector aan het schoolverlatersonderzoek en anderzijds de relatief lage respons, waardoor een oververtegenwoordiging in de non-responsgroep ontstaat. Een vergelijkbare situatie - oververtegenwoordiging in de deelname en lage respons - bestaat voor de schoolverlaters van de gemeente Amsterdam. Om te voorkomen dat hier een

10. Zie bijvoorbeeld Van Smoorenburg, Rutjes en Van der Velden (1995).

11. Dit beeld wordt overigens bevestigd door een vergelijking te maken met de Onderwijsmatrix van het CBS. 
oververtegenwoordiging zou optreden in de non-responsgroep is vooraf al een aantal onderwijsinstellingen uit deze gemeente bij het non-responsonderzoek buiten beschouwing gelaten.

Voor het uitvoeren van het telefonisch onderzoek onder de non-respondenten is - naast de lijst die voor het kunstvakonderwijs is gebruikt - gebruik gemaakt van een drietal verschillende vragenlijsten: één voor schoolverlaters van AVO/VBO, één voor die van het MBO en één voor die van het $\mathrm{HBO}$. Aan de hand van die lijsten is onder andere informatie verzameld over de gevolgde opleiding van de non-respondent, de belangrijkste bezigheid op het moment van enquêteren en (indien van toepassing) over de huidige baan. Aan alle non-respondenten is tevens gevraagd naar de reden waarom men in eerste instantie niet heeft deelgenomen aan het onderzoek.

\section{Tabel 5.1}

Redenen van schoolverlaters om in eerste instantie niet deel te nemen aan het onderzoek in percentages per schooltype

\begin{tabular}{lrrrrrr}
\hline Reden & $\begin{array}{c}\text { AVO } \\
\%\end{array}$ & $\begin{array}{c}\text { VBO } \\
\%\end{array}$ & $\begin{array}{c}\text { MBO kort } \\
\%\end{array}$ & $\begin{array}{c}\text { MBO } \\
\%\end{array}$ & $\begin{array}{c}\text { HBO } \\
\%\end{array}$ & $\begin{array}{c}\text { Totaal } \\
\%\end{array}$ \\
\hline Geen echte reden & 11 & 7 & 14 & 7 & 5 & 7 \\
Vragenlijst nooit ontvangen & 7 & 9 & 12 & 7 & 11 & 10 \\
Vragenlijst kwijtgeraakt & 6 & 1 & 4 & 0 & 3 & 3 \\
Vergeten & 27 & 24 & 12 & 16 & 16 & 17 \\
Geen interesse & 6 & 15 & 5 & 18 & 7 & 8 \\
Invullen kost teveel tijd/moeite & 27 & 24 & 33 & 28 & 33 & 32 \\
Bedenkingen bij anonimiteit en/of privacy & 1 & 3 & 2 & 1 & 3 & 3 \\
Vragenlijst was niet op mij van toepassing & 5 & 3 & 4 & 4 & 5 & 5 \\
Zegt vragenlijst al te hebben teruggestuurd & 6 & 1 & 4 & 5 & 6 & 5 \\
lets anders & 4 & 15 & 12 & 14 & 11 & 11 \\
& & & & & & \\
\hline
\end{tabular}

Tabel 5.1 laat per schooltype zien wat de redenen van weigering door de non-respondenten zijn geweest. Hierbij gaat het dus om de non-respondenten die in eerste instantie niet hebben deelgenomen aan het onderzoek, maar wel aan de telefonische enquête. De belangrijkste reden waarom schoolverlaters de vragenlijst niet hebben ingevuld en teruggestuurd is dat het invullen teveel tijd of moeite kost. Daarnaast geven vooral AVO'ers en VBO'ers aan dat zij zijn vergeten de vragenlijst in te vullen en/of terug te sturen. Bij schoolverlaters van het kort MBO en de afgestudeerden van het $\mathrm{HBO}$ is ook de bereikbaarheid een belangrijke reden van niet responderen. Overigens moet worden bedacht dat er bij het telefonisch benaderen van de non-respondenten wederom non-respons optreedt. De belangrijkste reden voor deze 'tweede non-respons' is dat de schoolverlaters zijn verhuisd of dat het telefoonnummer verkeerd is. Expliciet wordt opgemerkt dat bij het telefonisch non-respons onderzoek er naar is gestreefd om uit een zo klein mogelijke groep een vast aantal schoolverlaters te benaderen. In totaal zijn 3.002 mensen benaderd voor 1482 geslaagde gesprekken. 
Vervolgens kan worden nagegaan of de responsgroep en de groep die aanvankelijk niet op de schriftelijke enquête heeft gereageerd op de eerder genoemde kernvariabelen bestemming en betaald werk - van elkaar verschillen. De significantie van dit verschil kan worden bepaald aan de hand van de toets van Fisher (zie bijvoorbeeld Van der Genugten (1986, blz. 298-304)). Voordat deze Fisher-toets kan worden toegepast, is het echter noodzakelijk om eerst enkele aanpassingen in de databestanden van zowel de nonresponsgroep als de responsgroep door te voeren. Ten eerste zijn degenen waarvan de opleidingssector niet bekend is uit het non-responsbestand verwijderd ${ }^{12}$. Ten tweede zijn de afgestudeerden van het kunstvakonderwijs die telefonisch gereageerd hebben bij de respons buiten beschouwing gelaten, dit om dubbeltellingen te voorkomen. Verder is de verdeling naar opleidingssector verschillend tussen het responsbestand en het non-responsbestand. Om hiervoor te corrigeren - en dus beide bestanden op dit punt vergelijkbaar te maken - is ten derde het responsbestand zodanig (opnieuw) gewogen dat de verdeling over de opleidingssectoren overeenkomt met die van het non-responsbestand ${ }^{13}$.

Tabel 5.2 laat per schooltype voor elke bestemmingscategorie het resultaat van de toets van Fisher zien. Voor de volledigheid is aangegeven hoe de bestemming van de non-responsgroep en de responsgroep er in aantallen en percentages uit ziet. De aantallen voor de responsgroep zijn daarbij, zoals gezegd, zodanig aangepast dat de verdeling van de schoolverlaters over de opleidingssectoren binnen het desbetreffende schooltype gelijk is aan de verdeling binnen dat schooltype in het non-responsbestand ${ }^{14}$. De aantallen in de twee kolommen vormen de basis voor het berekenen van de z-score.

Uit de tabel blijkt dat bij het AVO, VBO en kort MBO het percentage schoolverlaters met bestemming leerlingwezen of in-service onderwijs in het non-responsbestand significant groter is dan in het responsbestand. Dit betekent dat het percentage schoolverlaters dat een opleiding in het leerlingwezen of in-service onderwijs volgt, op basis van het gebruikte onderzoeksbestand onderschat zou worden. Mogelijker heeft dit echter te maken met de manier van vraagstelling, die noodzakelijkerwijs verschilt tussen een telefonisch en een $\begin{array}{llllllllllllll} & c & h & r & i & f & t & e & i & i & j & k\end{array}$ Tabel 5.2

Toets van Fisher op selectiviteit naar bestemming tussen respondenten en non-respondenten per schooltype

12. Dit betreft met name VBO-schoolverlaters uit Amsterdam.

13. In principe zou het ook mogelijk zijn geweest om het non-responsbestand te herwegen naar het (al dan niet gewogen) responsbestand. Aangezien echter het non-responsbestand sterk scheef verdeeld is over de opleidingssectoren, zou dit leiden tot zeer hoge en dus onbetrouwbare weegfactoren.

14. Uiteraard zou men de verdelingen nog meer op elkaar kunnen afstemmen door bijvoorbeeld ook rekening te houden met het geslacht. Dit is echter niet gedaan omdat de aantallen in het nonresponsbestand daarvoor te klein zijn. 
AVO

Ilw/in-service

betaald werk

studie

werkloos

anders

VBO

Ilw/in-service

betaald werk

studie

werkloos

anders

MBO-kort

Ilw/in-service

betaald werk

studie

werkloos

anders

MBO

Ilw/in-service

betaald werk

studie

werkloos

anders

HBO

betaald werk

studie

werkloos

anders

$\begin{array}{rr}12 & 10 \\ 8 & 7 \\ 92 & 79 \\ 1 & \\ 3 & \end{array}$

$\begin{array}{ll}15 & 27 \\ 13 & 23\end{array}$

$22 \quad 39$

35

35

$\begin{array}{ll}17 & 20 \\ 41 & 48\end{array}$

$17 \quad 20$

911

11

$\begin{array}{rr}8 & 6 \\ 92 & 64 \\ 38 & 27 \\ 4 & 3 \\ 0 & 0\end{array}$

$\begin{array}{rr}748 & 79 \\ 94 & 10 \\ 67 & 7 \\ 38 & 4\end{array}$

$\begin{array}{rrr}145 & 5 & 2,53^{*} \\ 315 & 11 & -1,37 \\ 2.353 & 81 & -0,59 \\ 30 & 1 & -0,18 \\ 45 & 2 & 0,87\end{array}$

$\begin{array}{rrc}114 & 12 & 3,29^{*} \\ 187 & 19 & 0,71 \\ 626 & 64 & -3,84^{*} \\ 18 & 2 & 1,79 \\ 22 & 2 & 1,45\end{array}$

$\begin{array}{rrr}128 & 12 & 2,09^{*} \\ 540 & 51 & -0,53 \\ 277 & 26 & -1,27 \\ 75 & 7 & 1,18 \\ 34 & 3 & -1,05\end{array}$

271

4

1,10

4.421

62

0,53

$-0,44$

$-0,61$

2684

$-1,38$

a. Exclusief telefonische respons (kunstvakonderwijs).

b. Gewogen naar de verdeling over de opleidingssectoren in het non-responsbestand. De hier gepresenteerde aantallen wijken derhalve af van de in de (landelijke) rapportages genoemde aantallen.

* Significant op 5\%-niveau

onderzoek. In de telefonische enquête onder de non-respondenten is gevraagd of men een opleiding in het leerlingwezen of in-service onderwijs volgt zonder expliciet te vragen naar de belangrijkste bezigheid. In de schriftelijke vragenlijst daarentegen is voor de bestemming als uitgangspunt genomen het antwoord op de vraag hoe de schoolverlaters zichzelf vooral zien. Het kan zo zijn dat iemand die een opleiding in het leerlingwezen of in-service onderwijs volgt zichzelf meer als betaald werkende of als scholier/student beschouwt. Wanneer tevens naar de z-scores bij de bestemmingen betaald werk en studie wordt gekeken dan blijkt de bestemming studie bij deze schooltypen juist overschat te zijn (al dan niet significant). 
Of er sprake is van selectiviteit tussen de respons en de non-responsgroep in de antwoorden op de vraag 'Heb je op dit moment (ook) betaald werk? (inclusief een betaalde bijbaan en/of een leer-arbeidsplaats)' is weergegeven in tabel 5.3. Bij alle schooltypen is de fractie betaald werkenden onder de non-respondenten iets groter dan onder de respondenten. Alleen bij het $\mathrm{HBO}$ is er overigens sprake van een significant verschil tussen de respons- en de nonresponsgroep. De non-responsgroep bevat relatief gezien meer betaald werkenden dan de responsgroep.

Tabel 5.3

Toets van Fisher op selectiviteit in het aandeel betaald werkende respondenten en het aandeel betaald werkende non-respondenten per schooltype

\begin{tabular}{|c|c|c|c|c|c|}
\hline Betaald werk & \multicolumn{2}{|c|}{ Non-respons } & \multicolumn{2}{|c|}{ Respons $^{\mathrm{a}, \mathrm{b}}$} & Z-score \\
\hline AVO & & & & & \\
\hline $\begin{array}{l}\text { ja } \\
\text { nee }\end{array}$ & $\begin{array}{l}67 \\
49\end{array}$ & $\begin{array}{l}58 \\
42\end{array}$ & $\begin{array}{l}1.684 \\
1.382\end{array}$ & $\begin{array}{l}55 \\
45\end{array}$ & 0,60 \\
\hline VBO & & & & & \\
\hline $\begin{array}{l}\text { ja } \\
\text { nee }\end{array}$ & $\begin{array}{l}34 \\
22\end{array}$ & $\begin{array}{l}61 \\
39\end{array}$ & $\begin{array}{l}570 \\
482\end{array}$ & $\begin{array}{l}54 \\
46\end{array}$ & 0,96 \\
\hline MBO-kort & & & & & \\
\hline & $\begin{array}{l}61 \\
23\end{array}$ & $\begin{array}{l}73 \\
27\end{array}$ & $\begin{array}{l}853 \\
322\end{array}$ & $\begin{array}{l}73 \\
27\end{array}$ & 0,00 \\
\hline$M B O$ & & & & & \\
\hline $\begin{array}{l}\text { ja } \\
\text { nee }\end{array}$ & $\begin{array}{r}118 \\
24\end{array}$ & $\begin{array}{l}83 \\
17\end{array}$ & $\begin{array}{l}5.805 \\
1.492\end{array}$ & $\begin{array}{l}80 \\
20\end{array}$ & 1,04 \\
\hline $\begin{array}{l}H B O^{c} \\
\text { ja } \\
\text { nee }\end{array}$ & $\begin{array}{r}442 \\
45\end{array}$ & $\begin{array}{r}91 \\
9\end{array}$ & $\begin{array}{r}5.745 \\
839\end{array}$ & $\begin{array}{l}87 \\
13\end{array}$ & $2,25^{*}$ \\
\hline
\end{tabular}

a. Exclusief telefonische respons (kunstvakonderwijs).

b. Gewogen naar de verdeling over de opleidingssectoren in het non-responsbestand. De hier gepresenteerde aantallen wijken derhalve af van de in de (landelijke) rapportages genoemde aantallen.

c. Exclusief kunst en cultuur vanwege een verschil in vraagstelling ten opzichte van de rest van het $\mathrm{HBO}$.

* Significant op 5\%-niveau

\section{Besluit}

Dit werkdocument geeft de methodologische verantwoording van het schoolverlatersonderzoek zoals dat door het ROA wordt uitgevoerd. Naast een overzicht van de opzet van dit onderzoek, de gehanteerde classificaties en de uitgevoerde controles en toegepaste correcties op het databestand, is vooral ingegaan op de dekkingsgraad (de 'steekproefomvang') en de respons. Ook de eventuele selectiviteit van de respons is 
onderzocht. Behalve dit werkdocument is er voor gebruikers van het databestand een documentatieklapper beschikbaar.

Uit het gepresenteerde overzicht van dekkingsgraden blijkt dat het schoolverlatersonderzoek erg grootschalig van opzet is. Met name in het HBO is de steekproefomvang erg hoog te noemen. Hierdoor is het mogelijk om op zeer gedetailleerd niveau van opleidingen betrouwbare uitspraken te doen over de arbeidsmarktpositie van afgestudeerden. Bij het MBO en vooral het voortgezet onderwijs is de dekkingsgraad beduidend lager (12-25\%), maar voldoende groot om op redelijk gedetailleerd niveau een landelijk beeld te verkrijgen van de bestemming van schoolverlaters.

De respons is met gemiddeld $55 \%$ voor dit type onderzoek goed te noemen. Bij het kort MBO is de respons echter aan de lage kant. Een belangrijke vraag daarbij is of de respons selectief is. Dit blijkt nauwelijks het geval te zijn. Wel is het zo dat werkende HBO'ers iets vaker responderen. Verder wijst het uitgevoerde non-respons onderzoek er op dat degenen die doorstromen naar het leerlingwezen in de respons zijn ondervertegenwoordigd. Dit verschil kan echter ook veroorzaakt zijn door een (noodzakelijkerwijs) iets andere vraagstelling in de normale schriftelijke vragenlijst en het telefonische non-respons onderzoek. De algemene conclusie mag echter zijn dat op basis van het uitgevoerde onderzoek een goed en betrouwbaar beeld van de bestemming en arbeidsmarktpositie van schoolverlaters wordt verkregen.

\section{Literatuur}

Genugten, B.B. van der (1986), Inleiding tot de waarschijnlijkheidsrekening en mathematische statistiek deel 1, Stenfert Kroese, Leiden-Antwerpen.

Loo, P.J.E. van de, R.K.W. van der Velden, H.M. Zuurbier (1997), De arbeidsmarktpositie van afgestudeerden van het hoger beroepsonderwijs. HBO-Monitor 1996, Voorlichtingsdienst HBO-Raad, Den Haag.

Loo, P.J.E. van de, E.J.T.A. Willems, K.J. Pagrach (1997), De arbeidsmarktpositie van afgestudeerden van het hoger beroepsonderwijs. HBO-Monitor 1996. Statistisch supplement, Voorlichtingdienst HBORaad, Den Haag.

Ramaekers, G.W.M. (1997), WO-monitor economie 1996. Basismeting cohort '95, ROA-R-1997/4, Maastricht.

ROA (1997a), Schoolverlaters tussen onderwijs en arbeidsmarkt 1996, ROA-R-1997/3, Maastricht.

ROA (1997b), Kerngegevens. Schoolverlaters tussen onderwijs en arbeidsmarkt 1996, ROA-R-1997/3B, Maastricht.

Smoorenburg, M.S.M. van, J.J. Rutjes en R.K.W. van der Velden, Technisch werkdocument RUBS 1994, de uitstroom en bestemming van schoolverlaters van het schooljaar 1992-1993, ROA-W1995/4, Maastricht. 


\title{
Appendix A: Kernvragenlijst
}

Tabel A.1

Overzicht kernvragen Schoolverlatersinformatiesysteem

Variabele

Opmerking

\section{Algemeen}

Geslacht

Leeftijd

Etniciteit

Toestemming doorgeven gegevens aan school

Onderwijsloopbaan

Gevolgde opleiding

Voltijd- of deeltijdvariant van gevolgde opleiding

$\mathrm{HBO} / \mathrm{WO}$

Begindatum gevolgde opleiding

Einddatum gevolgde opleiding

Diploma of certificaat behaald van gevolgde opleiding

Opnieuw kiezen van gevolgde opleiding

Hoogste vooropleiding

Vooropleiding voor hoogste vooropleiding

LLW of in-service opleiding

LLW of in-service werk of stageplaats

LLW of in-service diploma/gestopt

Aansluiting LLW of in-service opleiding op gevolgde opleiding

Opnieuw kiezen LLW of in-service opleiding

Vervolgopleiding

Voltijd- of deeltijdvariant van vervolgopleiding

Vervolgopleiding diploma/gestopt

Plaats van vervolgopleiding

Aansluiting vervolgopleiding op gevolgde opleiding

Opnieuw kiezen vervolgopleiding

Cursus/bedrijfsopleiding

Cursus/bedrijfsopleiding totale duur

Cursus/bedrijfsopleiding aantal uren per week

LAO/MBO/HBO/WO

$\mathrm{MBO} / \mathrm{HBO} / \mathrm{WO}$

$\mathrm{HBO} / \mathrm{WO}$

$\mathrm{AVO} / \mathrm{VBO} / \mathrm{MBO}$

AVO/VBO/MBO

AVO/VBO/MBO

AVO/VBO/MBO

AVO/VBO(excl.LAO)

\section{Arbeidsmarktintrede}

Maatschappelijke positie sinds schoolverlaten

Verwijzing: (ook) betaald werk

Actief gezocht naar werk tijdens of na opleiding

Begin actief zoeken naar werk

Betaald werk gewenst aantal uren

Betaald werk laatste 4 weken gezocht

Beschikbaar betaald werk

Reden niet beschikbaar voor betaald werk

Inschrijving arbeidsbureau

Huidige functie begindatum

\author{
AVO/VBO(excl.LAO) \\ niet voor AVO \\ $\mathrm{MBO} / \mathrm{HBO} / \mathrm{WO}$ \\ $\mathrm{MBO} / \mathrm{HBO} / \mathrm{WO}$
}

bij kunst zowel betaalde als onbetaalde werkkringen 
Tabel A.1 (vervolg)

Overzicht kernvragen Schoolverlatersinformatiesysteem

Variabele

Opmerking

Huidige functie werving

Huidige functie beroep SBC 92

$\mathrm{MBO} / \mathrm{HBO} / \mathrm{WO}$

Huidige functie branche SBI 93

Huidige functie personeelsomvang bedrijf

$\mathrm{MBO} / \mathrm{HBO} / \mathrm{WO}$

Huidige functie vestigingsplaats bedrijf

$\mathrm{MBO} / \mathrm{HBO} / \mathrm{WO}$

Huidige functie dienstverband

Huidige functie aanstelling

Huidige functie vereist opleidingsniveau volgens werkgever

Huidige functie vereist opleidingsniveau volgens schoolverlater

Huidige functie vereiste opleidingsrichting volgens werkgever

Huidige functie vereiste opleidingsrichting volgens schoolverlater

niet bij AVO

niet bij AVO, LAO en kunst

Huidige functie leidinggeven

Huidige functie arbeidsuren per week

Huidige functie bruto maandinkomen

Huidige functie aansluiting met gevolgde opleiding

Nevenfuncties

Nevenfuncties aantal uren per week

Opleiding-huidige functie: belang van kennis en technieken

Opleiding-huidige functie: belang van vaardigheden

Opleiding-huidige functie: belang van houdingsaspecten

Opleiding-huidige functie: aandacht voor kennis en technieken

Opleiding-huidige functie: aandacht voor vaardigheden

Opleiding-huidige functie: aandacht voor houdingsaspecten

LAO/MBO/HBO/WO
$\mathrm{MBO} / \mathrm{HBO} / \mathrm{WO}$
$\mathrm{MBO} / \mathrm{HBO} / \mathrm{WO}$
$\mathrm{MBO}$ (beperkt)/HBO/WO
$\mathrm{MBO}$ (beperkt)/HBO/WO
$\mathrm{MBO}$ (beperkt)/HBO/WO
$\mathrm{MBO}$ (beperkt)/HBO/WO
$\mathrm{MBO}$ (beperkt)/HBO/WO
$\mathrm{MBO}$ (beperkt)/HBO/WO

